\title{
ASSESSMENT OF CYTOTOXIC ACTIVITY OF MILK WHEY ENRICHED WITH MAGNESIUM AND MANGANESE PARTICLES
}

\author{
O. Kochubei-Lytvynenko, O. Chernyshok \\ National University of Food Technologies \\ N. Dmytrukha, O. Lahutina \\ SI "Institute for Occupational Health of NAMS of Ukraine"
}

\begin{tabular}{|c|c|}
\hline Key words: & ABSTRACT \\
\hline Milk whey & \multirow{9}{*}{$\begin{array}{l}\text { The article is dedicated to the analysis of cytotoxicity of milk } \\
\text { whey, enriched by magnesium and manganese particles, } \\
\text { obtained by electrical discharge dispergation of metal pellets } \\
\text { in the milk whey. It is determined that enrichment of milk } \\
\text { whey with magnesium and manganese particles did not } \\
\text { cause changes in its properties, which could influence signi- } \\
\text { ficantly the resiliency and morphology of cells line HEK- } \\
293 \text {, L-929, RTR. HEK- } 293 \text { cells line was the most suscep- } \\
\text { tible to the influence of both endemic milk whey and milk } \\
\text { whey enriched with magnesium and manganese particles. It } \\
\text { could indicate that kidney cells have higher sensitivity com- } \\
\text { paring to other ones. }\end{array}$} \\
\hline sium and & \\
\hline manganese bioelement & \\
\hline & \\
\hline & \\
\hline Test-object in vitro & \\
\hline Cell culture & \\
\hline Cytotoxicity & \\
\hline $\begin{array}{l}\text { Artic } \\
\text { ived } 0\end{array}$ & \\
\hline
\end{tabular}

24.05.2017

Accepted 17.06.2017

Corresponding author:

O. Kochubei-Lytvynenko

E-mail:

npnuht@ukr.net

DOI: $10.24263 / 2225-2924-2017-23-4-22$

\section{ОЦНЮВАННЯ ЦИТОТОКСИЧНОї АКТИВНОСТІ МОЛОЧНОÏ СИРОВАТКИ, ЗБАГАЧЕНОї ЧАСТИНКАМИ MAГHIЮ I MAHГAHY}

\author{
О.В. Кочубей-Литвиненко, О.А. Чернюшок \\ Національний університет харчових технологій \\ Н.М. Дмитруха, О.С. Лагутіна \\ ДУ «Інститут медицини праці НАМН Украӥни»
}

Стаття присвячена вивченню циитотоксичної дії молочної сироватки, збагаченої частинками магнію $і$ мангану, отриманих методом електроіскрового диспергування гранул металів у ї̈ середовищі. Встановлено, щзо збагачення молочної сироватки частинками магнію і мангану не викликало змін ї властивостей, які б могли суттєво вплинути на життєздатність та мор- 
фологію клітин ліній НЕК-293, L-929, РТР. Найбільш вразливими до дї молочної сироватки, як нативної, так й збагаченої частинками магнію і мангану, виявились клітини лінії НЕК-293, щчо може вказувати на більщу чутливість клітин нирок порівняно з іншими клітинами.

Ключові слова: молочна сироватка, частинки біоелементів магнію та мангану, електроіскрове оброблення, біологічні тест-об'єкти in vitro, культура клітин, ичитотоксичність

Постановка проблеми. Мінеральні речовини - мікроелементи відносяться до ессенціальних, життєво необхідних компонентів їжі, що виконують в організмі людини важливі фізіологічні функції. Вони беруть участь в обміні речовин, у процесах кровотворення, росту, розмноження, диференціювання i стабілізації клітинних мембран, у тканинному диханні, функціонуванні нервової, ендокринної та імунної систем тощо [1-2].

Макро- та мікроелементи в організм людини надходять 3 питною водою, їжею, а також з мінеральними та вітамінно-мінеральними комплексами, біологічно-активними добавками. Проте проблема дефіциту цілого ряду мінеральних речовин у раціоні харчування середньостатистичної людини залишається недостатньо вирішеною. На особливу увагу заслуговують так звані біоелементи або біогенні елементи, що забезпечують життедіяльність організму людини [2].

До життєво необхідних біоелементів відносяться кальцій, фосфор, сірка, калій, натрій, магній, залізо, мідь, цинк, манган, молібден, кобальт, хром, селен, йод [2]. Дефіцит цих макро- і мікроелементів в організмі супроводжується специфічними структурними й функціональними порушеннями, тому збагачення продовольчої сировини та харчових продуктів біоелементами $\epsilon$ актуальним.

Найбільш поширеним способом поповнення дефіциту мінеральних речовин у харчових продуктах є внесення солей неорганічних кислот. Однак більшість відомих препаратів погано розчиняються у воді, мають неприємний гіркий смак, що може негативно вплинути на органолептичні властивості харчових продуктів, а це $\epsilon$ неприпустимим згідно з вимогами збагачення харчових продуктів [3]. До того ж мінерали в такій формі мають низьку біологічну доступність, а, як відомо, до основних ознак біоелементів відносять саме ї високу засвоюваність і відповідну форму знаходження в організмі (сполуки, аналогічні природнім) [2].

Сучасні наукові досягнення відкривають широкі перспективи для виробництва та використання нових форм препаратів біогенних металів, зокрема, у вигляді гідратованих чи цитратованих наночастинок металів (наноаквахелатів), отриманих внаслідок ерозійно-вибухової нанотехнології й електроіскрового диспергування струмопровідних гранул металів [4; 5]. На сьогодні препарати біогенних металів, створені із залученням нанотехнологій, починають використовувати в медицині, ветеринарії, сільському господарстві, парфумерній і харчовій продукції [6-9].

Застосування водних колоїдних розчинів металів у технології молочних продуктів, особливо молочних концентратів, нераціональне 3 огляду на 
додаткове додавання води. Тому в Національному університеті харчових технологій сумісно $з$ науковцями НУБІП України тривають дослідження щодо вивчення доцільності збагачення молочної сироватки цінними мінеральними елементами, зокрема магнієм і манганом, під час об'ємного електроіскрового диспергування струмопровідних гранул металів безпосередньо в її середовищі. Оброблення молочної сироватки в такий спосіб забезпечує іiі збагачення магнієм і манганом, що здатні утворювати металолігандові комплекси 3 компонентами молочної сироватки, а це сприятиме підвищенню їх біологічної доступності, та, власне, дозволить класифікувати як біоелементи [2].

Відомо, що $\mathrm{Mg}$ і $\mathrm{Mn}$ не тільки надають харчовим продуктам функціональних властивостей, оскільки $є$ активаторами й кофакторами багатьох важливих ферментів, що залучаються до обмінних процесів [1], але й відіграють істотну технологічну роль. Вони, наприклад, здатні активізувати i стабілізувати дію ферментів дріжджової клітини, сприяють зростанню молочнокислої мікрофлори тощо.

Отже, збагачення цінної вторинної молочної сировини магнієм і манганом $\epsilon$ актуальним і відкриває перспективи для розширення сфери ії використання. Проте відсутність відомостей про можливу небезпеку частинок металів, утворених електроіскровим диспергуванням струмопровідних гранул у середовищі молочної сироватки, обумовлює необхідність проведення відповідних токсиколого-гігієнічних досліджень.

Як правило, у вітчизняній і світовій практиці для доведення небезпечності речовин проводять дослідження на теплокровних тваринах. Проте сьогодення вимагає одержання інформації про токсичність та небезпечність речовин $\mathrm{i}$ продуктів за менш затратних способів, в експрес-режимі та більш гуманно, ніж традиційно визначеними методами експериментальних досліджень на лабораторних тваринах.

Нині активно розвиваються альтернативні методи in vitro на біологічних тест-об' єктах. Як моделі in vitro використовуються системи різної біологічної організації - безхребетні тварини, гідробіонти, мікроорганізми, рослини, культури клітин людини та тварин, а також молекулярні системи (білки, ферменти) [10-12]. In vitro-моделі придатні не тільки для отримання даних «дозавідповідь», а й для встановлення механізмів токсичної дії речовини [13-15].

За рекомендаціями ISO дослідження цитотоксичної дії речовин, у тому числі наночастинок і наноматеріалів, можуть проводитись на первинних культурах клітин і тканин, виділених з організму тварин, людини та перещеплювальних або постійних, отриманих 3 окремих видів пухлин. Таку оцінку проводять 3 використанням культур клітин: лімфоцитів крові людини; фібробластів, гепатоцитів, макрофагів гризунів; $з$ лімфоми мишей L5178Y; гепатокарциноми людини (Нер-G2); нормальних кератиноцитів людини (HaCat); недрібноклітинного раку легень людини (А-549) та інших. Вибір клітин-мішеней залежить від очікуваних біологічних ефектів досліджуваних речовин. Дослідження безпосередньо на культурі клітин людини спрощує екстраполяцію даних і прогнозування токсичності речовини відносно організму людини [12]. 
Мета дослідження: встановлення безпечності молочної сироватки, збагаченої частинками магнію і мангану, отриманих внаслідок електроіскрового диспергування гранул металів в іiі середовищі, альтернативним in vitro методом з використанням клітинних тест-об'єктів.

Матеріали і методи. Об'єкт досліджень: молочна сироватка 3-під сиру кисломолочного, збагачена частинками магнію і мангану внаслідок електроіскрового оброблення в розрядній камері зі струмопровідним прошарком гранул відповідних металів. Як контроль взято молочну сироватку з-під сиру кисломолочного, очищену від частинок білка.

Електроіскровий спосіб оброблення реалізовували на лабораторній установці, що складається з генератора розрядних імпульсів (частота імпульсів $0,2-2,0$ кГц; індуктивність розрядного контуру - 1 мкГ); розрядної камери 3 магнієвою або мангановою електродною системою та струмопровідним прошарком гранул відповідних металів; блоку управління; вимірювальних і допоміжних приладів. Як накопичувач енергії використовувався конденсатор ємністю 100 мкФ [5]. Оброблення здійснювали за таких параметрів: об'єм розрядної камери - $300 \mathrm{~cm}^{3}$; експозиція - 60 с; температура молочної сироватки - $(20 \pm 2)^{\circ} \mathrm{C}$.

Вміст металічних елементів у зразках сироватки визначали в лабораторії аналітичної хімії та моніторингу токсичних речовин ДУ «Інститут медицини праці НАМН України» методом атомно-емісійної спектрометрії з індуктивнозв'язаною плазмою на приладі Optima 210 DV (Perkin Elmer, США).

Розмір частинок встановлювали на аналізаторі дисперсності частинок Malvern Instruments Ltd., Велика Британія. pН визначали на іономірі універсальному И-160 М; окисно-відновний потенціал — платиновим електродом на іономірі універсальному ЕВ-74.

Дослідження цитотоксичної дії молочної сироватки, збагаченої магнієм і манганом внаслідок електроіскрового оброблення проводили на базі лабораторії промислової токсикології і гігієни праці при використанні хімічних речовин ДУ «Інститут медицини праці НАМН України» на культурах клітин лінії НЕК-293 (ембріональні клітини нирки людини), L-929 (перещеплювальна лінія фібробластів миші) та РТР (перещеплювальні клітини тестикулів поросят), отриманих з Інституту мікробіології і вірусології ім. Д.К. Заболотного НАН України.

Клітини, що використовували в експерименті, культивували в поживному середовищі RPMI 1640 ("SIGMA”, США), яке містило 4 ммоль/дм³ L-глутаміну, 10\% ембріональної сироватки теляти (“SIGMA”, США), 40 мкг/см ${ }^{3}$ гентаміцину в зволоженій атмосфері з $5 \% \mathrm{CO}_{2}$ за температури $37^{\circ} \mathrm{C}$. Зміну поживного середовища проводили кожні 2 доби. Пересів клітин здійснювали за допомогою розчину Версена при утворенні клітинами суцільного моношару.

Цитотоксичну активність досліджували за допомогою загальновизнаних тестів, а саме: визначення мітохондріальної активності (за МТТ-тестом) та синтезу білка (тестом фарбування сульфородаміном B (SRB-тест)) $[10,11]$.

$M T T-m е с m$ полягає у визначенні функціонування мітохондрій за активністю дегідрогеназ, що утворюють кристали з солями тетразолію[16]. Для виконання досліджень клітини висаджували на 96-лункові планшети в 
концентрації $1 \cdot 10^{5} / \mathrm{cm}^{3}$ по 100 мкл на лунку у повному поживному середовищі. Через 24 год до клітин вносили дослідні зразки молочної сироватки у природній концентрації з подальшим послідовним розведенням (1:2). Через 24 год культивування в середовище вносили барвник MTT (3-[4,5-Dimetilthiazole-2-yl]-2,5-diphenyltetrazolium bromide; Thiazolyl blue) (SIGMA, CШA)

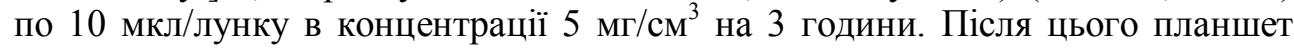
центрифугували (1500 об./хв протягом 5 хв), видаляли супернатант і додавали в кожну лунку по 50 мкл DMSO (диметилсульфоксид; SERVA) для розчинення кристалів формазану. Через 30 хв інкубації за кімнатної температури визначали оптичну густину вмісту лунок за довжини хвилі 540 нм за допомогою мультилункового спектрофотометру Sunrise Tecan (Австрія). За контроль були взяті лунки 3 клітинами в поживному середовищі, до яких не додавали досліджувану сироватку.

$S R B-m e c m$ використовували для визначення життєздатності клітин, за інтенсивністю синтезу білка в клітині. Для його проведення на 96-лункові планшети висаджували клітини в концентрації $1 \cdot 10^{5}$ /мл по 100 мкл на лунку в повному поживному середовищі. Через 24 год до клітин вносили дослідні зразки сироватки в природній концентрації 3 подальшим послідовним розведенням (1:2), інкубували їх за температури $37^{\circ} \mathrm{C}$ протягом 24 годин. Потім клітини фіксували 50\% розчином трихлороцтової кислоти (ТХО) (кінцева концентрація 10\%) протягом 1 год за температури $4^{\circ} \mathrm{C}$ і промивали проточною водою. Фіксовані у лунках клітини фарбували $0,4 \%$ розчином сульфородаміну Б (Sulforodamine B SIGMA, США) протягом 30 хв. Після видалення барвника лунки промивали $1 \%$ розчином оцтової кислоти і розчиняли барвник додаванням $10 \mu \mathrm{M}$ розчину Tris-base (10 хв на шейкері). Результати досліду реєстрували за допомогою мультилункового спектрофотометра Sunrise Tecan (Австрія) при довжині хвилі - 540 нм.

Результати і обговорення. Результати фізико-хімічних досліджень і дисперсного аналізу дослідних зразків молочної сироватки до та після електроіскрового оброблення представлені в табл.1.

Таблиця 1. Характеристика дослідних зразків молочної сироватки

\begin{tabular}{|c|c|c|c|c|c|}
\hline Номер зразка & $\mathrm{pH}$ & $\begin{array}{c}\text { OВ-потенціал, } \\
(-\mathrm{E}), \mathrm{MB}\end{array}$ & $\begin{array}{c}\text { Середній розмір } \\
\text { частинок, мкм }\end{array}$ & Вміст Mg, мг/кг & Вміст Мn, мг/кг \\
\hline 1 & $4,40 \pm 0,2$ & 10 & $0,562 \pm 0,23$ & $59,8 \pm 0,59$ & $0,015 \pm 0,002$ \\
\hline 2 & $4,75 \pm 0,2$ & 73 & $0,560 \pm 0,13$ & $170,0 \pm 5,08$ & $0,018 \pm 0,001$ \\
\hline 3 & $5,10 \pm 0,2$ & 102 & $0,536 \pm 0,39$ & $58,4 \pm 0,05$ & $0,069 \pm 0,003$ \\
\hline
\end{tabular}

Номер зразка: 1 - сироватка з-під сиру кисломолочного (контроль); 2, 3 - сироватка, оброблена в розрядній камері з шаром гранул металів між основними електродами магнію та мангану відповідно.

Під час досліджень відмічене підвищення окисно-відновного потенціалу в обробленій сироватці (підвищення антиоксидантних властивостей), що може свідчити як на користь проходження в системі процесу $\mathrm{M} \leftrightarrow \mathrm{M}^{\mathrm{n+}}+$ ne, так i на ймовірне комплексоутворення між іонами металів і біолігандами молочної сироватки, що, у свою чергу, приводить до підвищення біологічної доступності магнію й мангану в обробленій сироватці. 
Дисперсним аналізом дослідних зразків сироватки встановлено, що середній розмір частинок молочної сироватки до та після оброблення суттєво не відрізнявся. Оскільки токсичність системи може залежати від розміру диспергованих в сироватці частинок металів [17], додатково встановлювали середній гідродинамічний діаметр частинок магнію і мангану в колоїдних розчинах, отриманих електроіскровим диспергуванням гранул відповідних металів у водному середовищі за подібних до сироватки параметрів оброблення. Встановлено, що колоїдні розчини магнію і мангану мали частинки в нано- (близько 30 нм) і мікророзмірному діапазоні (від 100 нм до 10 мкм). При цьому середній розмір частинок у колоїдному розчині магнію складав $118 \pm 5$ нм, мангану $-270 \pm 11$ нм.

Дослідження цитотоксичних властивостей молочної сироватки, збагаченої частинками металів магнію й мангану, дали змогу встановити, що найбільшою цитотоксичною дією стосовно клітин НЕК-293 володіла, власне, сама сироватка молочна (24,3\% живих клітин). У дослідних зразках, збагачених магнієм і манганом, кількість живих клітин була дещо більшою - 26,4\% та $26,8 \%$ відповідно (рис. 1, позначення НР - нерозведена сироватка). Такий цитотоксичний ефект можливо обумовлений низьким $\mathrm{pH}$ усіх зразків сироватки (див. табл. 1), що сприяло зниженню життєздатних клітин за рахунок їх лізису. Відмічено, що зменшення концентрації сироватки в інкубаційному середовищі в 8 і більше разів (й, відповідно, підвищення $\mathrm{pH}$ середовища до рівня оптимального для функціонування клітин сприяло їх нормальному росту). Цитотоксична дія молочної сироватки, збагаченої частинками $\mathrm{Mg}$ й $\mathrm{Mn}$, була приблизно такою, як і в молочній сироватці до оброблення. Так, у розведенні 1:2 кількість живих клітин складала 55,4\% (сироватка з $\mathrm{Mg}$ ) та $49,3 \%$ (сироватка $3 \mathrm{Mn}$ ), а в розведеннях у 8 і більше разів спостерігалась нормальна життєдіяльність клітин подібно до звичайної сироватки. Кількість живих клітин була від 82 до 94,6\% порівняно з контролем.

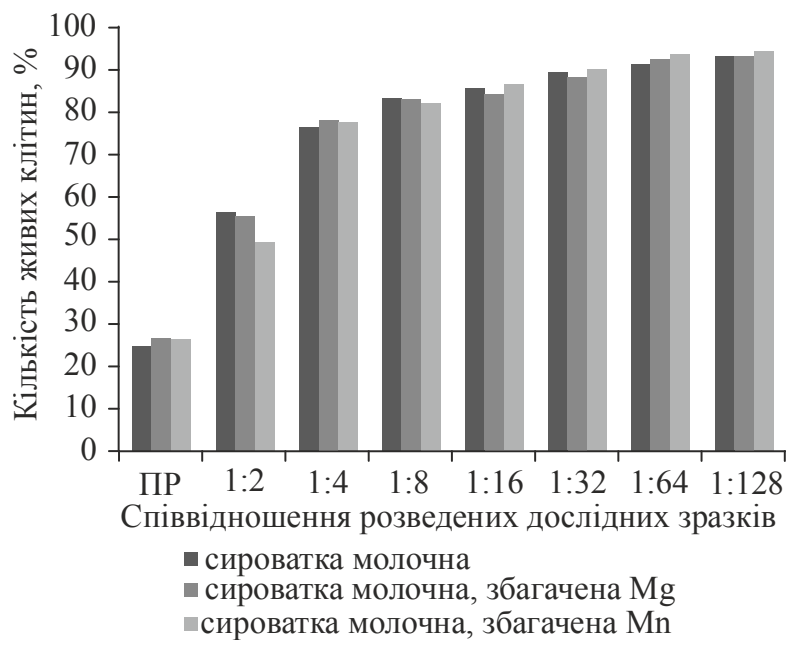

Рис. 1. Оцінка цитотоксичної дії молочної сироватки, збагаченої частинками Мg i Мn, на культури клітин лінії НЕК-293 (у МТТ-тесті) 
Дослідження, виконані на клітинах лінії L-929, показали, що зразки молочної сироватки, збагаченої частинками магнію і мангану, стимулювали проліферацію, яка сприяла підвищенню кількості живих клітин (більше ніж 100\% в контролі) (див. рис. 2). У той час як сироватка молочна за даними МТТ-тесту викликала зниження життєздатності клітин L-929 до 77\% в розведеннях 1:2, 1:4, 1:32 і 1:64, а за впливу інших концентрацій кількість живих клітин становила $80-90,5 \%$.

Слід зауважити, що при додаванні молочної сироватки 3 частинками магнію за розведення більше ніж у 32 рази, збільшення кількості живих клітин порівняно з контролем не спостерігалось. Відсоток живих клітин становив $85 . .95 \%$ подібно до звичайної сироватки. Аналізуючи ці дані, можна припустити, що проліферацію стимулює лише певна концентрація частинок магнію.

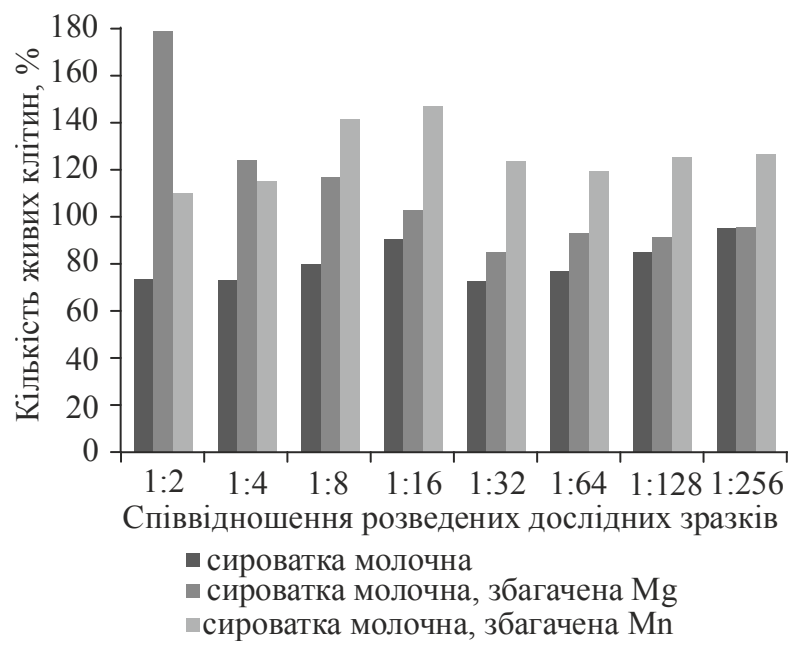

Рис. 2. Оцінка цитотоксичної дії молочної сироватки, збагаченої частинками Mg i Мn, на культури клітин лінії L-929 (у MTT-тесті)

Додавання молочної сироватки у розведенні 1:2 до клітин тестикулів поросят (клітини лінії РТР) викликало загибель 41,8\% клітин. Подальше розведення сироватки (у $8 . .64$ рази) суттєво не впливало на їх життєздатність (рис. 3).

Не відмічений цитотоксичний ефект для сироватки, збагаченої частинками магнію, - кількість живих клітин у зразках за розведення у $2-8$ разів становила від 94 до 98,5\%. За розведення понад 16 разів, тобто за нівелювання впливу $\mathrm{pH}$, навіть спостерігалось збільшення кількості живих клітин порівняно $з$ контролем (до 107,2...117,6\% ).

Зразки молочної сироватки із частинками мангану в перших трьох розведеннях спричиняли незначну цитотоксичну дію, кількість живих клітин при цьому була у межах $69,1 \ldots 87,3 \%$ подібно звичайній сироватці (рис. 3). Подальше розведення спричиняло зростання кількості живих клітин.

Тест із сульфородаміном В показав подібні до ММТ тесту результати й довів відсутність цитотоксичної дії сироватки 3 частинками магнію на 
клітини лінії РТР. Сироватка молочна, збагачена частинками $\mathrm{Mn}$, у перших трьох розведеннях знизила чисельність живих клітин до $70-90 \%$, тоді як подальше розведення більше ніж у 16 разів навпаки збільшувало кількість живих клітин тестикулів поросят у лунках, ніж у контролі (100\%).

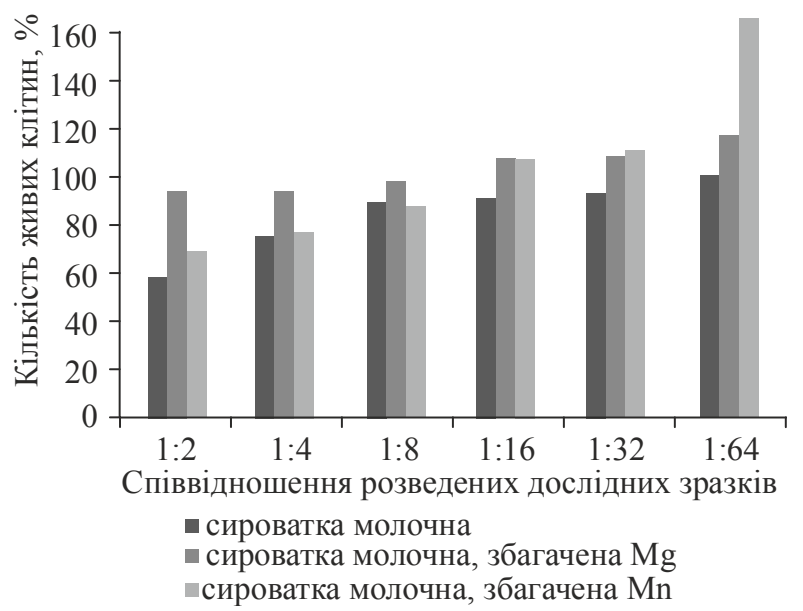

Рис. 3. Оцінка цитотоксичної дії молочної сироватки, збагаченої частинками Мg i Мn, на культури клітин лінії РTP (у МТТ-тесті)

Під час дослідження морфології клітин лінії РТР, пофарбованих сульфородаміном В, після інкубації їх з дослідними зразками молочної сироватки та сироватки, збагаченої магнієм і манганом, спостерігали зміни показані на мікрофотографіях (рис. 4).

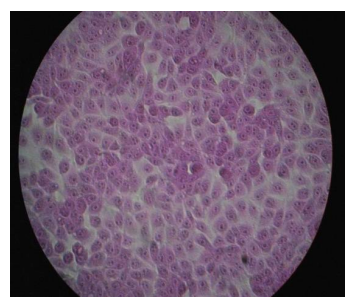

a)

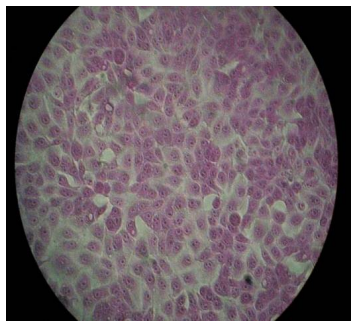

в)

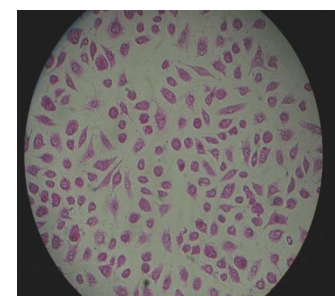

б)

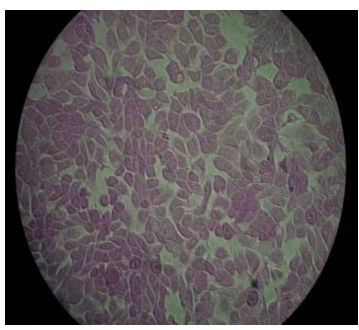

г)

Рис. 4. Дослідження морфології клітин лінії РТР, пофарбованих сульфородаміном В: контрольні клітини (a), після інкубації їх з молочною сироваткою (б), молочною сироваткою $з$ частинками магнію (в) та молочною сироваткою з частинками мангану (г) (розведення сироватки 1:2, збільшення $\times 100$ ) 
Встановлено, що сироватка молочна викликала порушення моношару, зміни форми, зменшення кількості клітин і їх загибель (рис. 4б). Проте сироватка 3 частинками $\mathrm{Mg}$ суттєво не впливала на життєздатність клітин, тому моношар та структура їх майже не змінилися порівняно 3 контролем (рис. 4a, в), тоді як сироватка 3 частинками Mn викликала незначне порушення моношару за рахунок втрати клітинних контактів і появу апоптичних клітин (рис. 4г).

\section{Висновки}

Отже, комплексом токсикологічних досліджень встановлено, що збагачення молочної сироватки частинками магнію і мангану внаслідок електроіскрового диспергування гранул відповідних металів в іiі середовищі не викликало потенційно шкідливих чинників, які б могли суттєво вплинути на життєздатність клітин лінії НЕК-293 (ембріональні клітини нирки людини), L-929 (перещеплювальна лінія фібробластів миші) та РТP (перещеплювальні клітини тестикулів поросят) та їх морфологічні ознаки.

Встановлено, що найбільшою цитотоксичною дією стосовно клітин ліній HEK-293, L-929 та РТР володіла нативна сироватка молочна. Після інкубації клітин 3 нерозведеною та розведеною у співвідношенні 1:2 нативною молочною сироваткою спостерігалась найменша кількість живих клітин, ніж після ii збагачення магнієм і манганом.

Зменшення кількості живих клітин після їх інкубування із зразками сироватки з-під сиру кисломолочного пояснюється низьким $\mathrm{pH}$ середовища $(\mathrm{pH} 4,4)$, тоді як для нормального культивування дослідних клітин характерний діапазон значень рН в межах 5,9-7,3.

Цитотоксична дія нерозведеної або розведеної вдвічі молочної сироватки, збагаченої частинками магнію і мангану, на всі дослідні клітинні тест-об'єкти була менш вираженою порівняно із нативною молочною сироваткою. За розведення понад 8-16 разів, тобто за нівелювання впливу $\mathrm{pH}$, спостерігалось збільшення кількості живих клітин лінії L-929 та РTP порівняно з контролем.

Дослідження, виконані на клітинах лінії L-929, показали, що зразки молочної сироватки, збагаченої частинками магнію і мангану, стимулювали проліферацію, яка сприяла підвищенню кількості живих клітин порівняно із контролем.

Найбільш вразливими до дії молочної сироватки, як нативної, так й обробленої електроіскровими розрядами, виявились клітини лінії НЕК-293, останнє може вказувати на те, що клітини нирок людини є більш чутливими до токсичного впливу ніж інші досліджувані клітинні лінії.

\section{Лiтература}

1. Спиричев В.Б. Обогащение пищевых продуктов витаминами и минеральными веществами. Наука и технология / В.Б. Спиричев, Л.Н. Шатнюк, В.М. Позняковский; под общ. ред. В.Б. Спиричева. - 2-е изд. - Новосибирск : Сиб. универ. изд-во, 2005. — 548 с.

2. Скальный А.В. Биоэлементы в медицине / А.В. Скальный, И.А. Рудаков. - Москва : Издательский дом «Оникс 21 век»: Мир, 2004. - 272 с.

3. Кукин М.Ю. Разработка технологий цитрата аммония-железа, лактата магния и комплексных пищевых добавок и их применение в пищевых продуктах: автореф. ... канд. техн. наук : спец. 05.18.07 «Биотехнология пищевых продуктов и биологических 
активных веществ» / Кукин Михаил Юрьевич ; Санкт-Петербург : нац. исслед. ун-т информац. технологий, механики и оптики. - СПб., 2013. - 22 с.

4. Патент України на корисну модель № 29856. Спосіб отримання аквахелатів нанометалів «Ерозійно-вибухова нанотехнологія отримання аквахелатів металів» // Косінов Н.В., Каплуненко В.Г. / МПК (2006): В01J 13/00, В82В 3/00. Опубл. 25.01.2008. Бюл. № 2. 2008.

5. Лопатько К.Г. Образование наноразмерной фракции металлов при электроискровой обработке гранул / К.Г. Лопатько, В.В. Олишевский, А.И. Маринин, Е.Г. Афтандилянц // Электронная обработка материалов. - 2013. - № 49(6). - С. 80-85.

6. Ткаченко C.В. Передумови використання препаратів з твердою фазою в нанорозмірному стані у якості каталізаторів процесів харчових виробництв // Продовольчі ресурси: зб. наук. праць. Серія Технічні науки. - 2015. - С. 18-22.

7. Сердюк А.M. Нанотехнології мікронутріснтів: питання безпечності та біотичності наноматеріалів при виробництві харчових продуктів / А.М. Сердюк, М.П. Гуліч, В.Г. Каплуненко, Н.В. Косімов // Академія медичних наук України. — 2010. — № 3, Т.16 - С. 467-471.

8. Дробот B.I. Використання цитратів цинку та магнію, одержаних методом нанотехнології, у хлібопеченні / В.І. Дробот, Ю.В. Бондаренко, В. Г. Каплуненко // Міжнародна наукова конференція, присвячена 130-річчю НУХТ «Нові ідеї в харчовій науці — нові продукти харчовій промисловості», 13-17 жов. 2014 р., м. Київ. - Київ : Національний університет харчових технологій, 2014. - С. 60.

9. Українець A.I. Коагуляційне очищення жомопресової води гелем алюмінію / А.I. Українець, В.В. Олішевський, Н.М. Пушанко, К.В. Ляпіна, А.І. Маринін // Наукові праці НУХТ. - 2015. - Т. 21, № 5. - С. 237-243.

10. Альтернативні методи і тест-системи / І.М. Трахтенберг, В.М. Коваленко, Н.В. Кокшарева, П.Г Жмінько та ін. К.: ВД «Авіцена», 2008. - 268 с.

11. Clemedson C. ACuteTox - optimization and pre-validation of an in vitro test strategy for predicting human acute toxicity / C. Clemedson, B. Blaauboer, J. Castell, [et al.] // ALTEX. - 2006. - № 23 - P. 254-258.

12. Combes R.D. The use of human cells in biomedical research and testing // Alternatives to laboratory animals - 2004. — № 32. - P. 43-49.

13. Коваленко В.Н. Методы in vitro в токсикології ліків: стан та перспективи / В.Н. Коваленко, Л.Б. Бондаренко // Вісник фармакології та фармації. - 2005. - № 2. - С. 2-13.

14. MacGregor J.T. In vitro human tissue models in risk assessment: report of a consensusbuilding work-shop / J.T. MacGregor, J.M. Collins, Y. Sugiyama [et al.] // Toxicological Sciences. - 2001. - Vol. 59. - P. 17-36.

15. Takhar $P$. In vitro methods for nanotoxicity assessment: advantages and applications / P. Takhar, S. Mahant // Archives of Applied Science Research — 2011, № 3. - P. 389 - 403.

16. Borenfreund $E$. Comparison of two in vitro cytotoxicity assays - the neutral red (NR) and tertezolium (MTT) tests / E. Borenfreund, H. Babich, N. Martin-Alguacil // Toxicology in Vitro. - 1988. - Vol. 2, N. 1. - P. 1-6.

17. Андрусишина И.Н. Наночастицы металлов: способы получения, физико-химические свойства, методы исследования и оценка токсичности // Сучасні проблеми токсикології. - 2011. - № 3. - С. 4-14. 